\title{
The Thermal comfort for Excavated cliff buildings:Taba, Egypt as a case study
}

\author{
Ahmed A. Fikry ${ }^{\mathrm{a}}$, Abbas M. El Zafarany ${ }^{\mathrm{b}} \&$ Hala N. El Nawawii. ${ }^{{ }^{*}}$ \\ ${ }^{a}$ Professor of Architecture, Architecture Department, Faculty of Engineering, Cairo University, Egypt \\ ${ }^{\mathrm{b}}$ Professor of Environmental Design, Urban Design Department, Faculty of Urban planning, Cairo \\ University, Egypt
}

${ }^{\mathrm{c}}$ Phd Student, Architecture Department, Faculty of Engineering, Cairo University, Egypt

\begin{abstract}
The cliff buildings are building types characterized by location on cliffs and mountain slopes and terraces. The cliff buildings rang between three main types; the Exposed, the Semi excavated, and the totally excavated. The high cliff buildings are featured by altitude over the sea level, which give an advantage to these type of buildings.

Egypt is characterized by hot arid desert climate with extended coastal, and in some places with high rock formations, like mountains and hills. The Sinai Peninsula is featured by mountain formation overlooking the Red Sea. The Tourism sector benefits from plain coastal in order to build their villages with negligence for the site formation and its advantages. The mountainous regions represent opportunities for investment and development, but it suffers from lack of attention and negligence. It is assumed as barren and semi-arid areas inhabited by the minority, mostly Bedouins and indigenous people.

The objective of this paper is to test the cliff buildings alternatives ability to achieve thermal comfort inside spaces. Therefore, the simulation is fulfilled by using Design Builder program for a separate touristic guest room with total built up area $100 \mathrm{~m}$. sq. in Taba, Egypt. The simulation measures air temperature inside spaces with varying in window to wall ratio and through the four main orientation directions. As to highlight on the importance of reconstructing buildings in Egyptian mountains, hills, and plateaus and the effect of these buildings on enhancing the environment by decreasing HVAC use and increasing thermal comfort. Whereas the totally excavated buildings with an exposed facade are within the comfort zone for the air temperature.
\end{abstract}

\footnotetext{
* Corresponding Author: Tel.: +02 01227056563

E-mail address: halanabil_eng@yahoo.com.
} 
Key words: Architecture; Cliff Building; Excavated building; Semi excavated building; Taba-Egypt; Thermal comfort

\section{Introduction}

The Egyptian topography varies between depressions and highlands. The territory of Egypt and the Sinai Peninsula ranges from mountains and plateaus in Southlands to the plane lands in Northlands. Throughout the history of Egyptian civilization, especially the Early ages, the Egyptian architecture was characterized by diversity and unity where adapted to natural topographic diversity as Mountains, Hills and plains. In spite of the arid climatic conditions especially in deserts, the thermal comfort and daylight were integrated with achieving human comfort inside spaces.

Ancient Egyptian civilizations had benefited from natural resources and topography in constructing different life aspects including the aesthetic aspects and architecture. The most important resources are the desert and the Nile. So caves were inhabited in Egypt and the surrounding eastern regions at the end of the Epipaleolithic era since 20,000 BC [1]. Therefore, the idea of constructing cliff buildings and refuge dwellings in mountains and hills is an idea that has existed since ancient times in Egyptian architecture.

The cliff building types differ in location and construction methods with the ability of excavating buildings in mountain rocks, therefore cliff buildings have many advantages, which encourage constructing in mountains and high lands such as open view, distinct climate, inner peace, and Serenity. In addition to that, the cliff buildings high altitude from Sea level improves inner space temperature.

\section{Mountain Climates}

The mountainous places are characterized by its unique climate. The climate of the mountain regions varies according to two main factors, the first one is the elevation from the sea level "Altitude", and the other one is the relief of Mountains, which obstructs the air movement and drives the air up [2]. Therefore, the climate of the mountain varies greatly from day to day and from at different altitudes and tendencies [3], as the mountains and high lands climate is differ than plane lands. Whereas, it characterized by vertical climate zones depending on altitude. These properties provide lower air temperature as high as the building location from sea level, as shown in Eq. 1.

Equation 1: The relation between altitude and air temperature [4]

$$
\mathrm{T}=\mathrm{T}_{0}-6.5 \mathrm{~h} / 1000
$$

Where $\mathrm{T}=$ Air Temperature $\left(\mathrm{C}^{0}\right), \mathrm{T}_{0}=$ Air temperature at sea level $\left(\mathrm{C}^{\mathrm{o}}\right), \mathrm{h}=$ Altitude $(\mathrm{m})$. 


\section{Excavated Cliff Buildings}

Cliff buildings are that constructed at the sloping cliff or have been excavated totally or partially on the sloping cliff, while excavated buildings relates to the word "excavate" which means digging or emptying the material by removing the contents to make a hole or tunnel, whether soil, rock, or other [5]. The excavated cliff building is developed from the primitive man shelter, where the excavated cliff buildings are manmade caverns to simulate the natural caves by drilling the rock [6].

Excavated buildings differ from other building types, since their features are the design of the interior spaces, while the exterior is the earth mass features [6-8].

\subsection{Excavated Cliff Buildings Backgrounds}

In the past, Natural caves were one of the main resources of human shelters; they provide protection from climatic conditions and wildlife. The primitive man took advantage from nature in proportion to his livelihood, with respect for surrounding environment geography and topography. Humans tried to benefit from natural resources and Topographic determinants; they began in digging holes, in addition to sculpture and decorative façades. Among the first areas is the places overlooking the Mediterranean Sea where the idea of shelter in caves or underground [7]. These areas are suffering from hot arid climate and dust storms.

Later on, humans expanded their power and lands by heading towards the plains for the availability of adequate livelihoods, thus he abandoned the highlands and the hard topography.

In the modern era, especially in the late twentieth century, the trend of underground architecture began with a new contemporary thought that was far from the negatives of an underground building, such as poor ventilation, narrow spaces, and humidity [7]. According to the building codes, the building should be well ventilated and lighted, by having openings from the sides or roof [9].

\subsection{Cliff buildings in Egypt}

Over the Egyptian history, many buildings partially or totally were excavated in Mountains especially in cliff edges along the Nile riverbanks and western desert. For example, along the Nile banks, the Middle Pharaonic dynasty excavated many tombs into the mountains [10]. The Bani Hassan funerary tombs in Al Minya City excavated totally in the steep slope plateau opposite the city of Abu Qurqas, Fig. 1. They referee to the eleventh and twelfth Pharaonic dynasty and consist of 39 tomb [1]. 

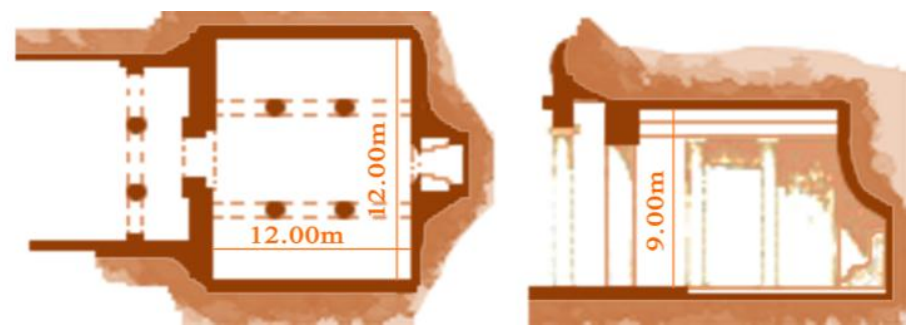

Fig. 1. One of Beni Hassan tombs floor plan \& section [1]

Otherwise on the West side of the Nile, the New Pharaonic dynasty tombs excavated totally in Thebes's steep slope hill known by the Kings Valley tombs. The tombs characterized by its depth through hill side and length below, the tomb reached up to $210 \mathrm{~m}$ length and $96 \mathrm{~m}$ depth [1]. The New Pharaonic dynasty presents great temples complexes, for example, the Hatshepsut mortuary Temple at Deir El-Bahri [10]. The temple partially excavated in the steep slope of Thebes Mountain, where the external mass built by natural stone, Fig. 2. The external masses consist of three external terraces reached by ramps until the rock cut sanctuary in the hill foot [1].
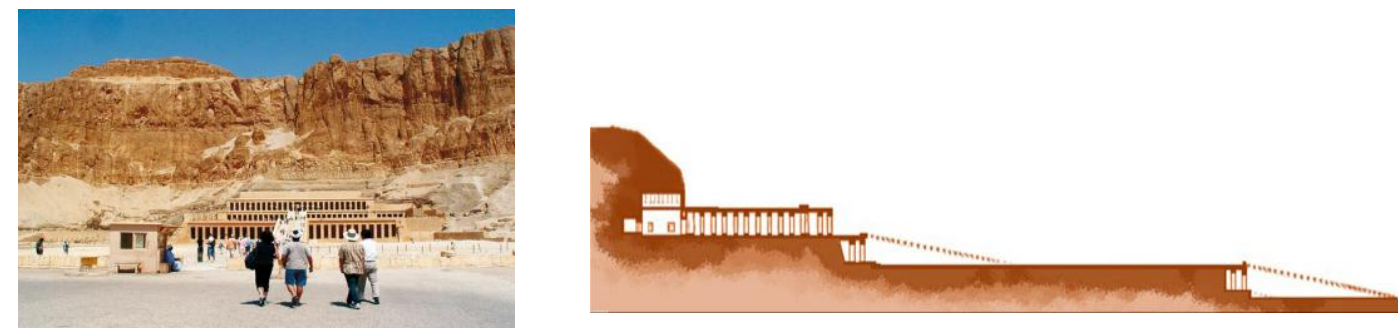

Fig. 2. Left: Front view for Hatshetsup-temple[11], Right: Hatshetsup temple cross section[12]

Also from the New Pharaonic dynasty is Abu Simbel temple and his wife's temple in Aswan City. The group consists of the Great Temple of Ramesses II and the small Temple. Both temples excavated totally in the hills with great cut rock statues for the king and Queen in temple's elevations. The government relocates the Great Temple to another place by keeping the same concept of rock cut to higherlevel land, Fig. 3. The great temple façade is $36 \mathrm{~m}$ wide $\mathrm{x} 32 \mathrm{~m}$ high and the small temple is $27.4 \mathrm{~m}$ wide $\mathrm{x} 12.2 \mathrm{~m}$ high with main hall $9 \mathrm{~m}$ high and $10 \mathrm{~m}$ high respectively [1].

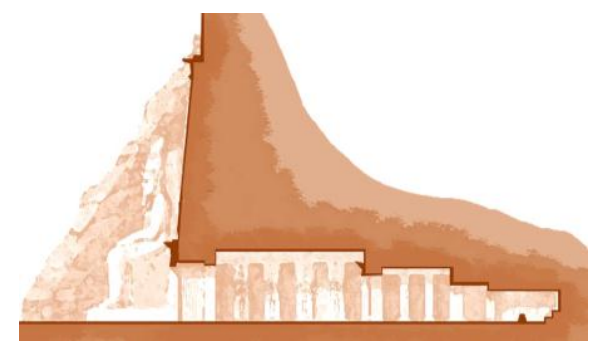

Fig. 3. Great Temple of Ramesses II Cross section [13] 
According to climate change and the energy crisis 1960 AD, the going back to the past architecture in order to solve these problems has begun through contemporary underground buildings and has begun to emerge in the so-called Earth movement with the aim of green architecture to conserve energy and reduce the consumption of fossil fuels [7].

The Church of St. Simeon the Tanner in Moqatam Mountain presents middle of twenty-century cliff architecture in Egypt, which differs in mass formation, because the external mass is integrating with a natural cave exists in the foot of the cliff mass. The church external mass characterized by intersection with the natural cave to create enclosure spaces, as shown in Fig. 4.
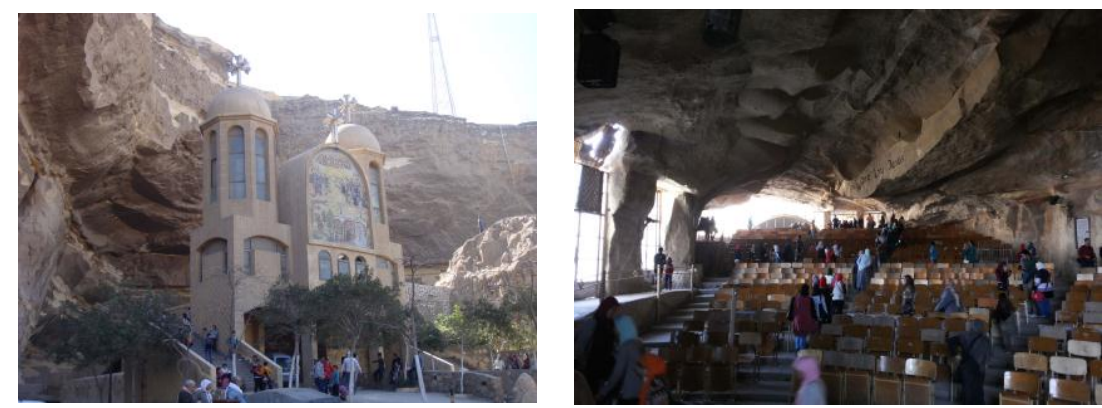

Fig. 4. Left. Church of St. Simeon the Tanner External Building, Right. Church of St. Simeon the Tanner main Auditorium, (Author, 2017)

\section{Methodology}

\subsection{Case Study description}

The case study is located in Taba, South Sinai in East Egypt. Taba is a coastal city overlooking the Red Sea. The climatic data based on Meteonorm weather data file (Longitude $\mathrm{E}^{\mathrm{o}}$ 34.895, Latitude $\mathrm{N}^{\mathrm{o}}$ 29.497, Altitude $\mathrm{m}$ a.s.1. $31 \mathrm{M}$ ) [14]. As ASHRAE Standard, the climate Zone definition is 1B [15]. The Climatic consultant 6.0 analysis shows that the summer weather is extremely hot, and almost cold in winter. The city is out of comfort zone almost all the year, Fig. 5.
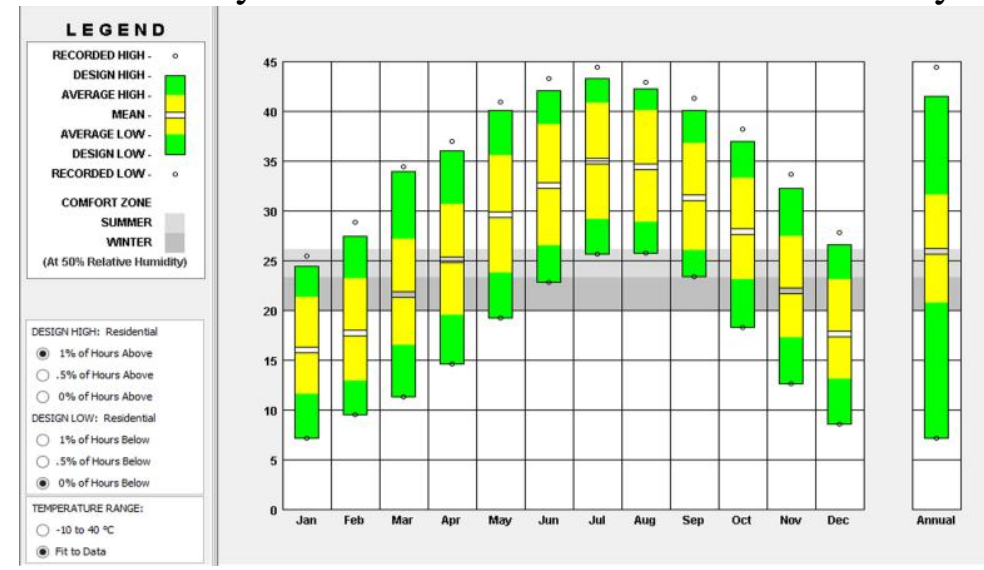

Fig. 5. Annual Temperature for Taba City from Climate Consultant 6 


\subsection{Case Study simulation parameters}

The model is built in Design Builder program, by using Energy plus as an engine for thermal simulation. The function of the model is a separate touristic guest room with $10 \mathrm{~m}$ depth, $10 \mathrm{~m}$ width, and clear height $3 \mathrm{~m}$ and is located $15 \mathrm{~m}$ above ground level in mountain mass of Limestone rock with conductivity $1.7000 \mathrm{w} / \mathrm{m}-\mathrm{k}$ and density $2200 \mathrm{Kg} / \mathrm{m}^{3}$. The Occupancy density is settled 0.04 people $/ \mathrm{m}$. Sq. with workday's occupancy 24/7. The models exposed façade glazing is assumed as double-glazing with specifications as shown in table 1.

Table 1. External Glazing specifications.

Façade specifications

\begin{tabular}{ccc}
\hline & Layers & Thickness \\
\hline Glazing Frame & Aluminum window frame (no break) & $50 \mathrm{~mm}$ \\
\hline External Glazing & $\begin{array}{c}\text { Double Glazing (clear glass } 6 \mathrm{~mm} . \text { - Air } \\
\text { gap 6 mm. - clear glass } 6 \mathrm{~mm} .)\end{array}$ & $18 \mathrm{~mm}$. \\
\hline
\end{tabular}

The simulation is applied by depending on natural ventilation, to show the real effect of the rock thermal mass on the inner spaces. The case study alternatives are represented in three types, which are the totally excavated; semi excavated and exposed with finishing materials suitable with the surrounding environment and compatible with model design, as shown in Table 2 and Table 3. An additional tested model is applied for simulation as underground building at $-2.00 \mathrm{~m}$ depth from ground level to show the difference between cliff building and underground building.

Table 2. Three case study design alternatives with finishing materials

\section{Building Type}

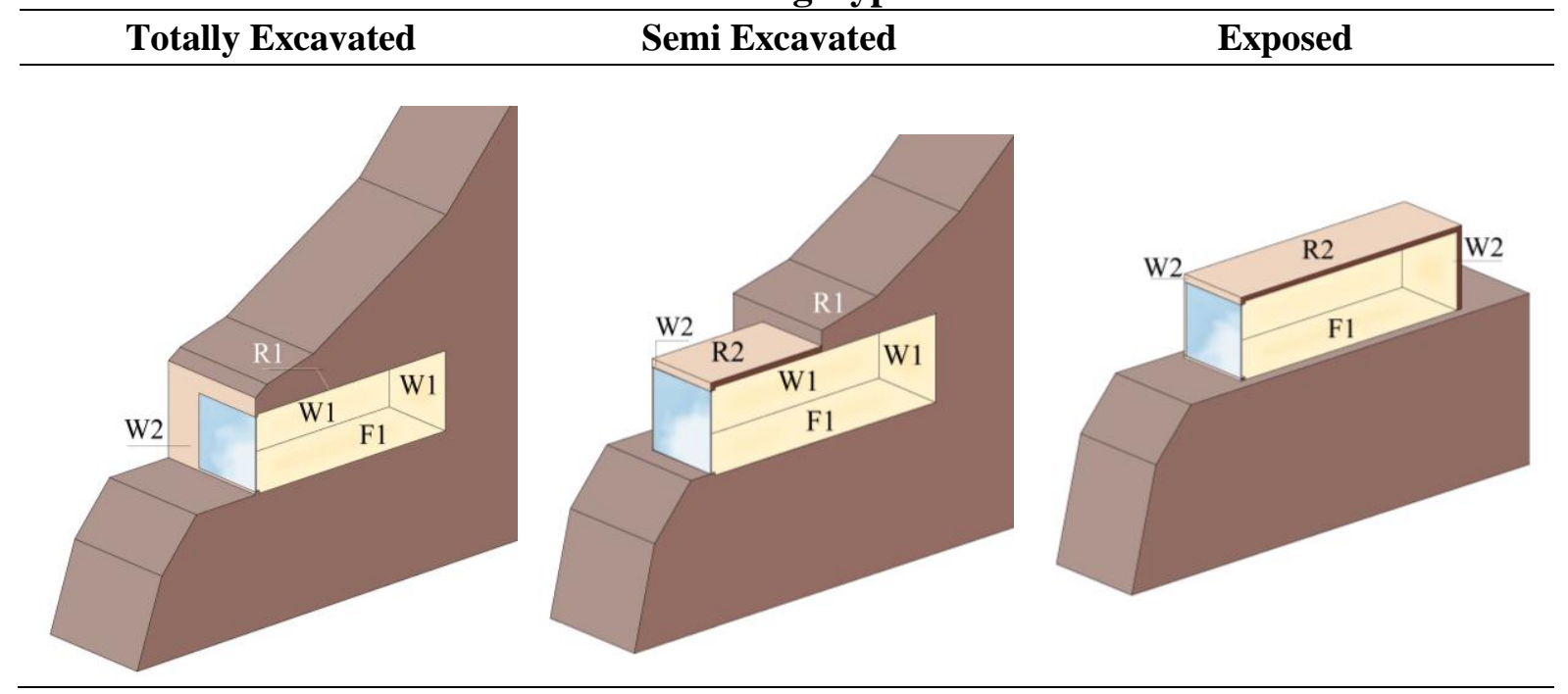


Table 3. The different finishes materials which used in the simulation process

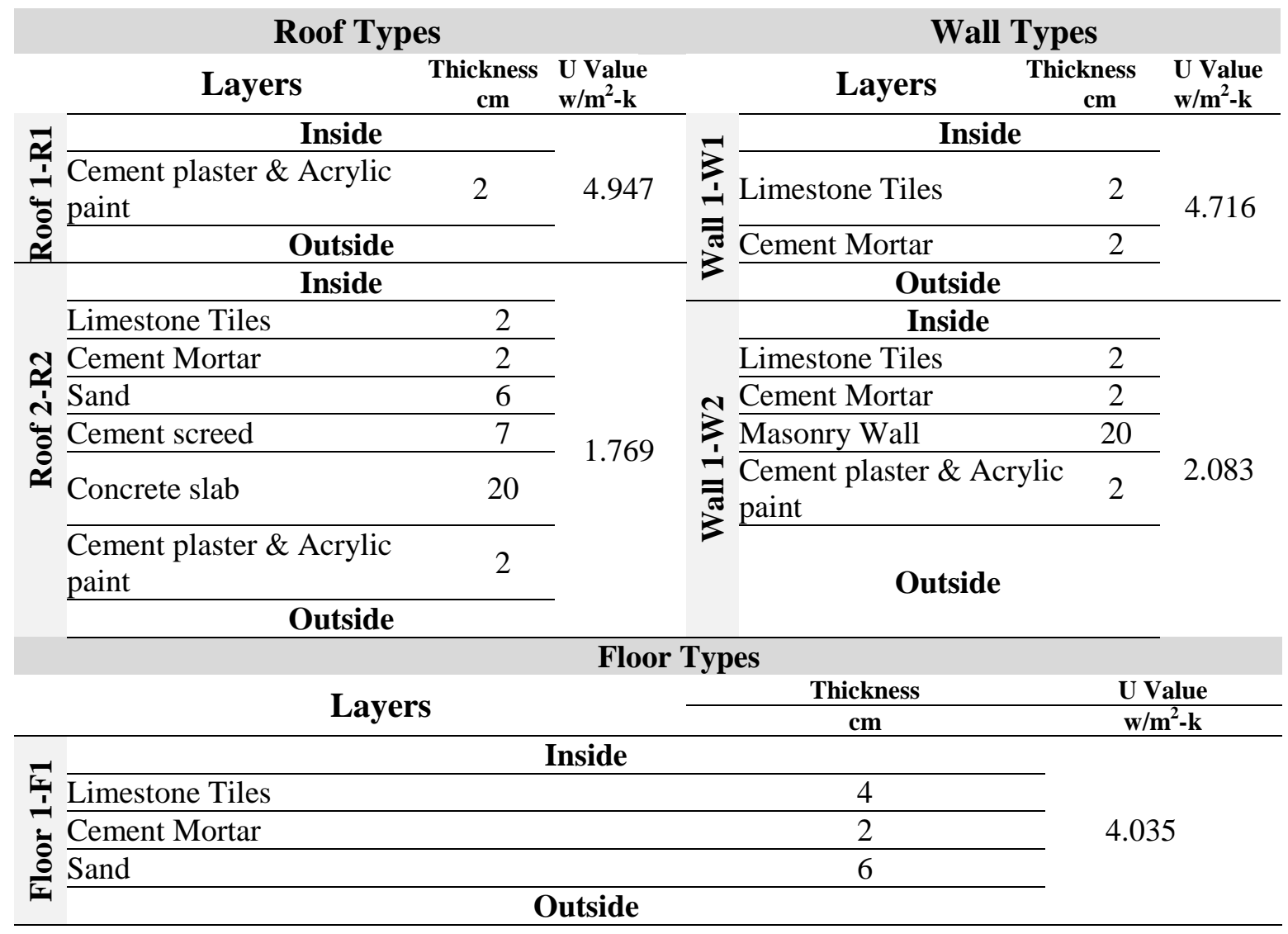

The simulation tests the inner space thermal comfort for the three model alternatives of the cliff buildings, where the simulation variables are represented in both the window to wall ratio (WWR \%) and the building orientation, as shown in Table 4. As the simulation is fulfilled for the three model alternatives by applying for the four main orientations.

Table 4. The exposed façade glazing variables.

Façade Glazing Area

\begin{tabular}{ccccccccccccc}
\hline Width & \multicolumn{10}{c}{ WWR (\%) } \\
\cline { 2 - 12 } \begin{tabular}{c}
$\mathbf{x}$ \\
\cline { 2 - 11 } \\
$\begin{array}{c}\text { Height } \\
(\mathbf{m})\end{array}$
\end{tabular} & 6.00 & $\mathrm{x}$ & 1.00 & 8.00 & $\mathrm{x}$ & 1.50 & 9.00 & $\mathrm{x}$ & 2.00 & 9.50 & $\mathrm{x}$ & 2.55 \\
\hline
\end{tabular}

\section{Results}

When the window to wall ratio is $20 \%$, the results show that the exposed buildings are totally out of the comfort zone all over the year. In addition to that, the air temperature fluctuation for the exposed building is greatly considerable all over the year. While the semi excavated is out of the comfort zone through hot and warm months. The air temperature fluctuates is moderate and increases in hot and warm 
months. By looking to the excavated building, the fluctuation between minimum and maximum air temperature is almost within comfort zone, as shown in Fig. 6.
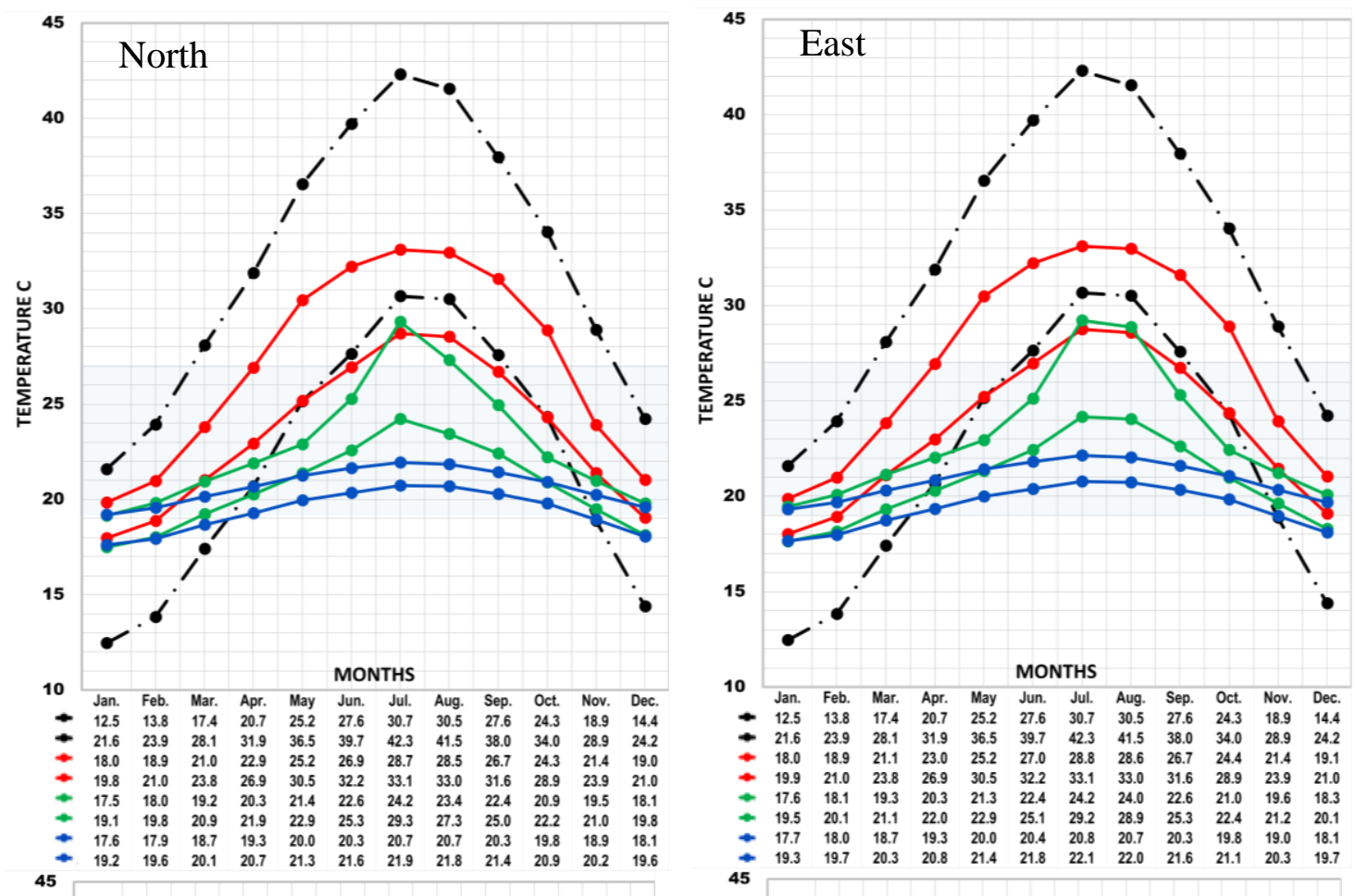

10 Jan. Feb. Mar. Apr. May Jun. Jul. Aug. Sep. Oct. Nov. Dec.

$\begin{array}{llllllllllll}\text { - } 12.5 & 13.8 & 17.4 & 20.7 & 25.2 & 27.6 & 30.7 & 30.5 & 27.6 & 24.3 & 18.9 & 14 .\end{array}$

$\begin{array}{lllllllllllll}21.6 & 23.9 & 28.1 & 31.9 & 36.5 & 39.7 & 42.3 & 41.5 & 38.0 & 34.0 & 28.9 & 24.2 \\ - & 18.0 & 189 & 21.1 & 23.0 & 25 . & 27.0 & 28.8 & 28.6 & 26.7 & 24.4 & 21.4 & 19.1\end{array}$

$\begin{array}{rlllllllllll}19.9 & 21.0 & 23.8 & 26.9 & 30.5 & 32.2 & 33.1 & 33.0 & 31.6 & 28.9 & 23.9 & 21.0\end{array}$

$\begin{array}{llllllllllll}17.6 & 18.1 & 19.3 & 20.3 & 21.3 & 22.4 & 24.2 & 24.0 & 22.6 & 21.0 & 19.6 & 18.3\end{array}$

$\begin{array}{llllllllllll}-19.5 & 20.1 & 21.1 & 22.0 & 22.9 & 25.1 & 29.2 & 28.9 & 25.3 & 22.4 & 21.2 & 20.1 \\ -17.7 & 18.0 & 18.7 & 19.3 & 20.0 & 20.4 & 20.8 & 20.7 & 20.3 & 19.8 & 19.0 & 18.1\end{array}$
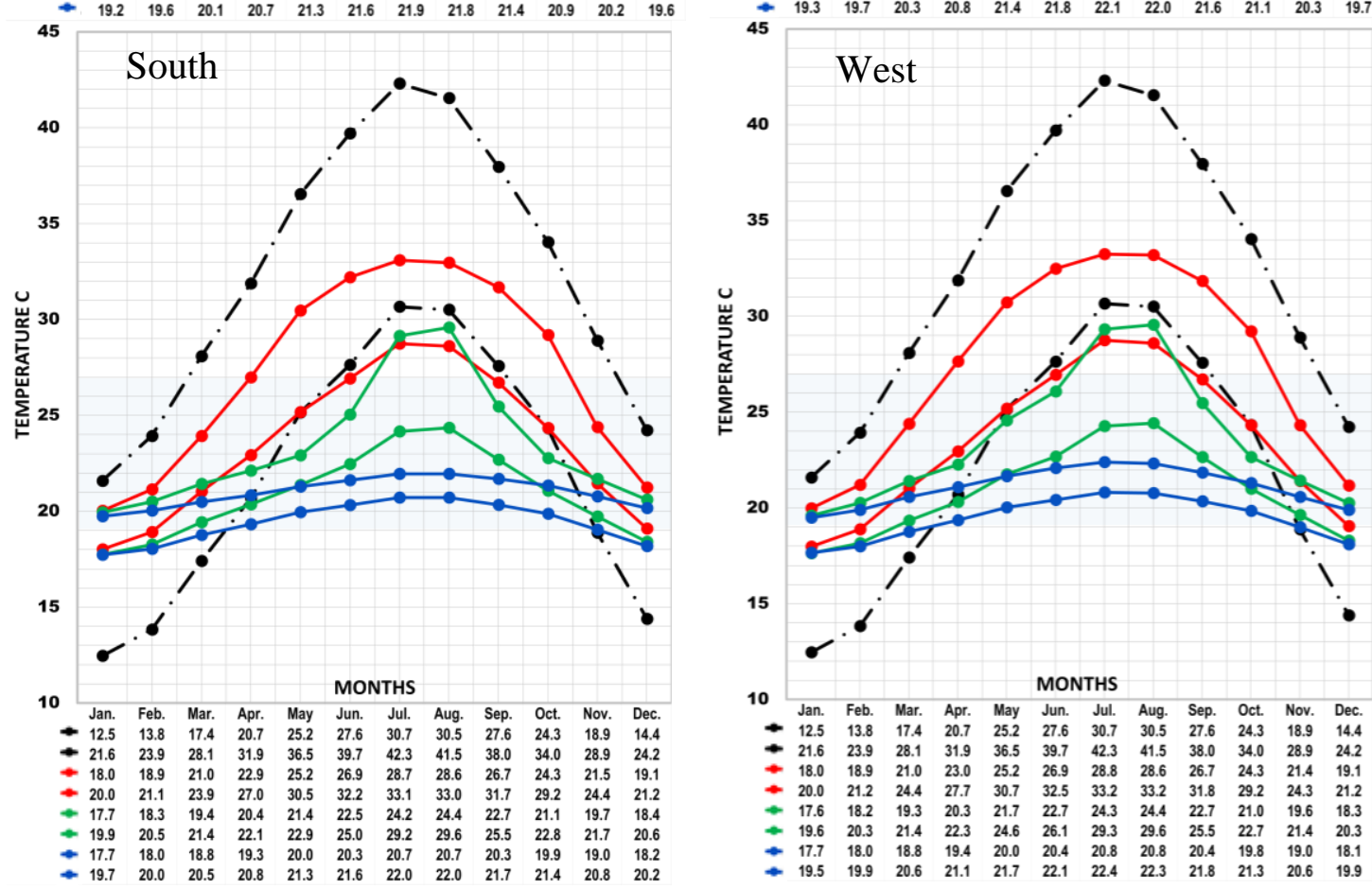

- Min. of Outside Dry-Bulb Temperature - Min. Temperature of Semi excavated Building

- Max. of Outside Dry-Bulb Temperature - Max. Temperature of Semi excavated Building

Comfort Zone

- Min. Temperature of Exposed Building - Min. Temperature of Excavated Building

- Max. Temperature of Exposed Building — Max. Temperature of Excavated Building

Fig. 6. The Min. and Max. temperature annually for all types with WWR 20\% 
Generally, the comparison for the four orientations shows almost the similar fluctuation between the minimum and maximum air temperature with minor increase in the West orientation.
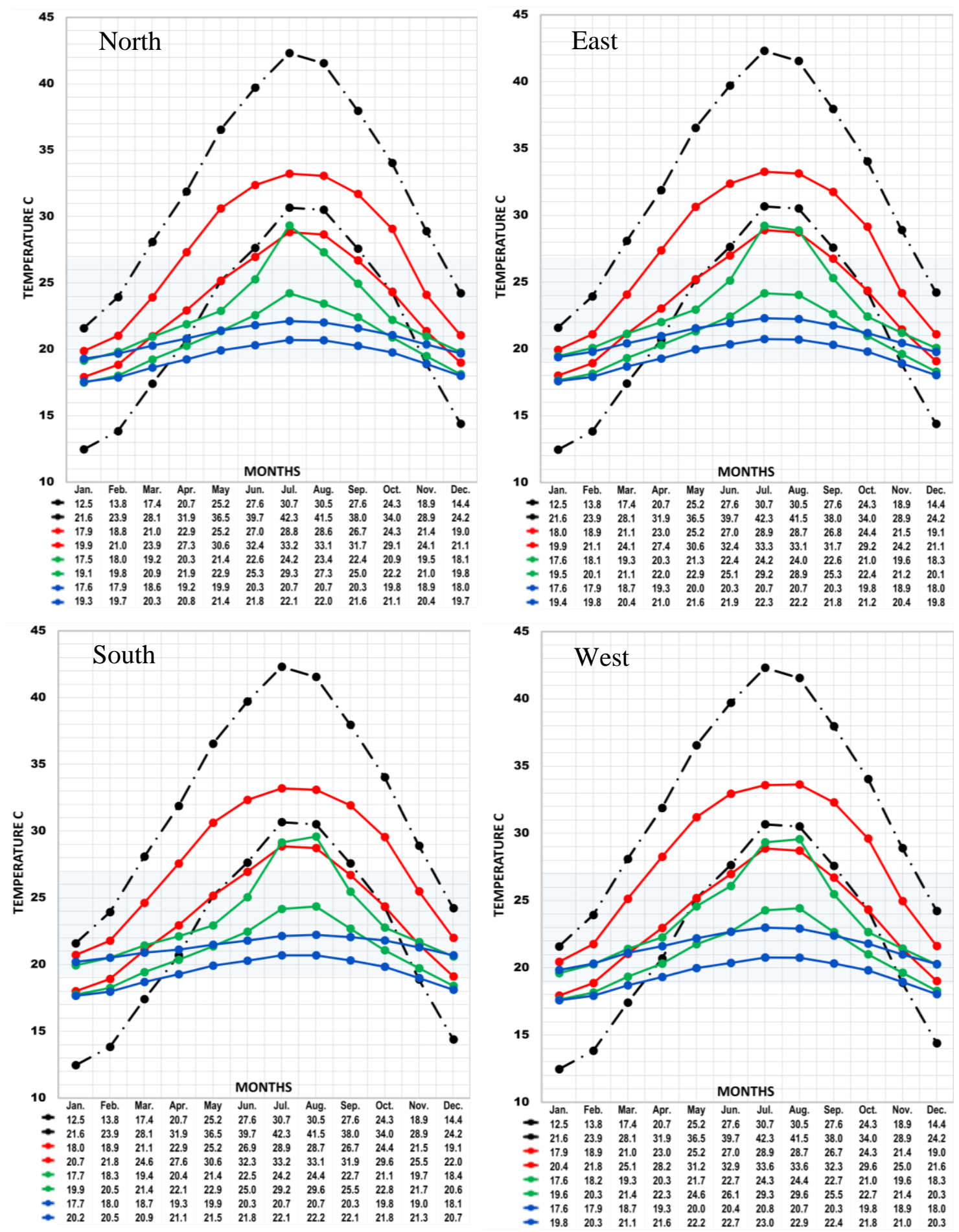

- Min. of Outside Dry-Bulb Temperature - Min. Temperature of Semi excavated Building

- Max. of Outside Dry-Bulb Temperature - Max. Temperature of Semi excavated Building

Comfort Zone

- Min. Temperature of Exposed Building — Min. Temperature of Excavated Building

- Max. Temperature of Exposed Building — Max. Temperature of Excavated Building

Fig. 7. The Min. and Max. temperature annually for all types with WWR 40\% 
By Re- simulating the three case study alternatives with WWR $40 \%$, the results are similar to WWR 20\%. Nevertheless, the maximum and minimum of the annual air temperature increased because of the increase in window size; in addition to that, the effect of the western orientation is clear as the fluctuation of the air temperature increases more than other orientations, as shown in Fig. 7.

Generally, the results for the three case study alternatives with WWR $60 \%$ and WWR $80 \%$ are similar to previous simulations with $20 \%$ and $40 \%$ WWR. Whereas, the maximum and minimum of the annual air temperature increased gradually for the $60 \%$ WWR models followed by the $80 \%$ WWR models. The west orientation has the major effect on the fluctuation of the air temperature, as shown in Fig. 8, Fig. 9, Fig. 10, and Fig. 11.
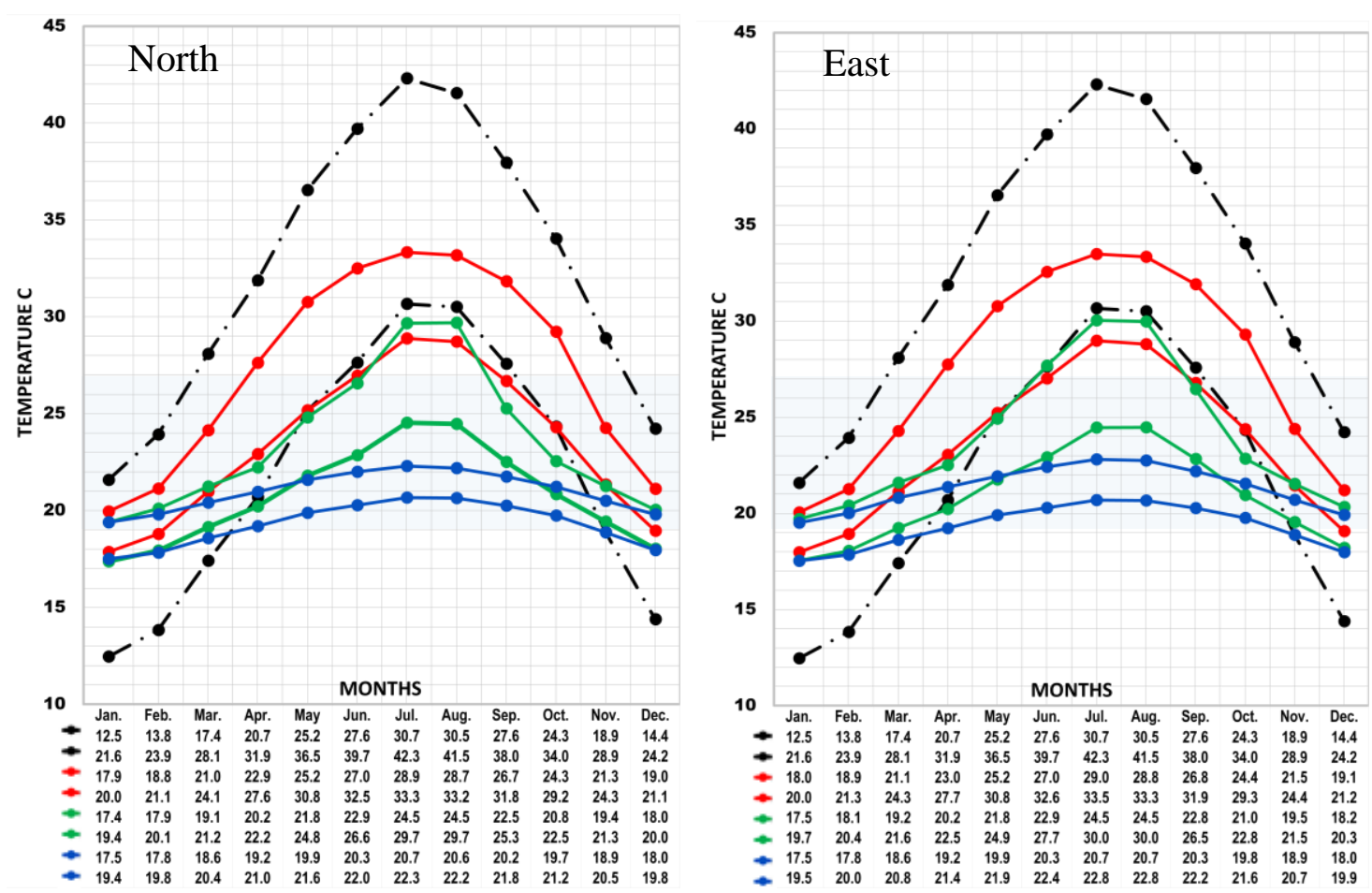

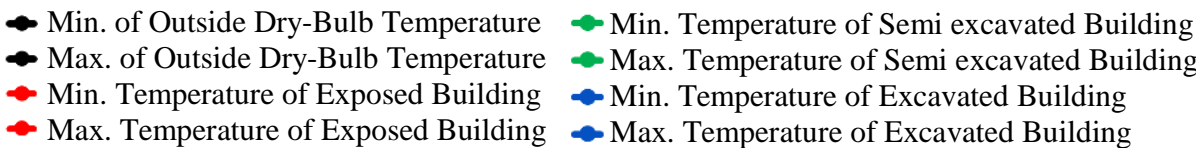

Fig. 8. The Min. and Max. temperature annually for all types with WWR $60 \%$ - Northern and Eastern orientations 

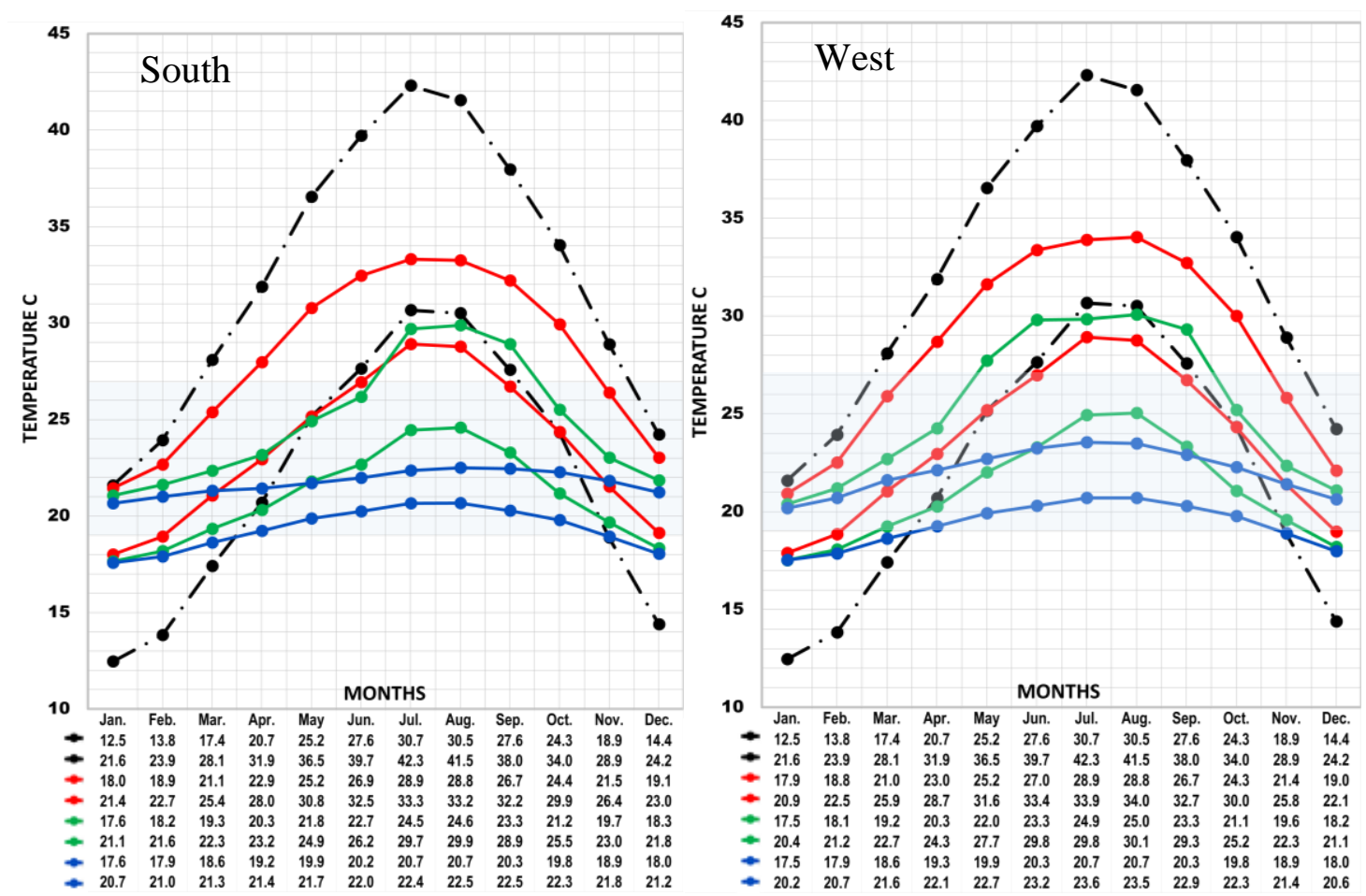

Fig. 9. The Min. and Max. temperature annually for all types with WWR 60\% - Southern and Western orientations
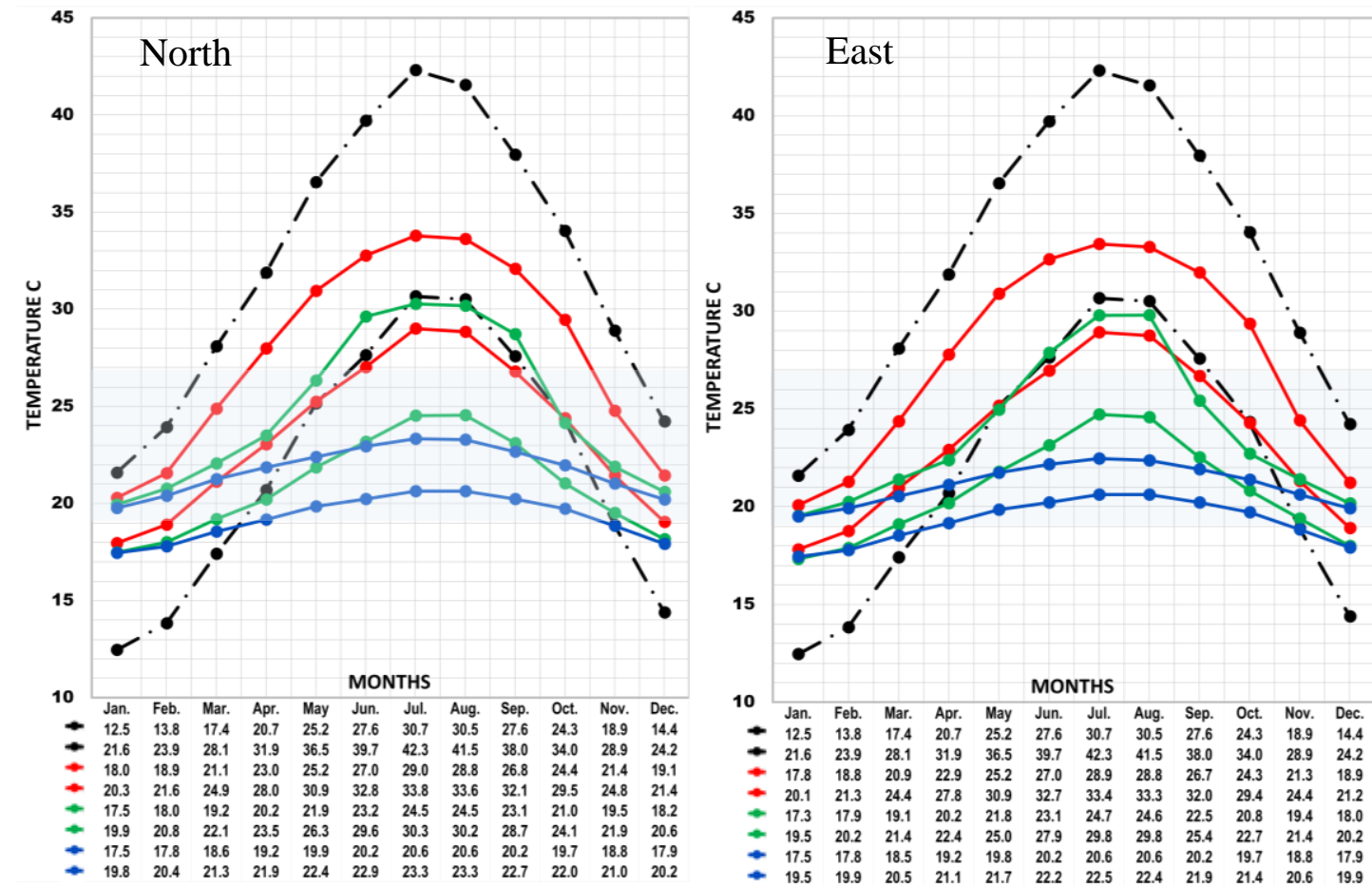

- Min. of Outside Dry-Bulb Temperature - Min. Temperature of Semi excavated Building $\square$ Comfort Zone

- Max. of Outside Dry-Bulb Temperature - Max. Temperature of Semi excavated Building

$\left(19^{\circ}-27^{\circ}\right)$

- Min. Temperature of Exposed Building — Min. Temperature of Excavated Building

- Max. Temperature of Exposed Building - Max. Temperature of Excavated Building

Fig. 10. The Min. and Max. temperature annually for all types with WWR 80\% - Northern and Eastern orientations 

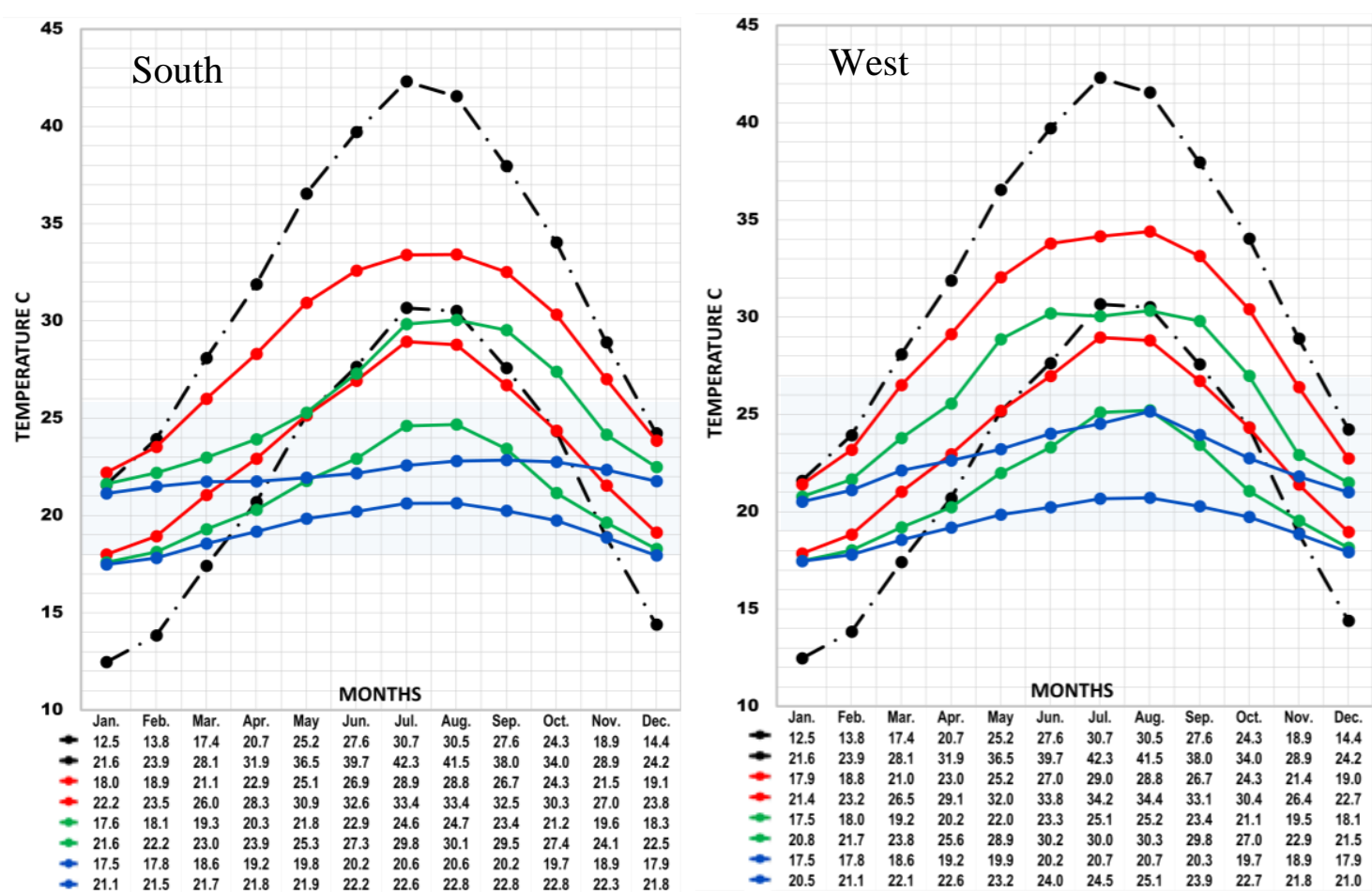

Fig. 11. The Min. and Max. temperature annually for all types with WWR 80\% - Southern and Western orientations

\section{Discussion}

As shown previously that the results of the totally excavated building is the most efficient among the other alternatives, where it is within the comfort zone almost all over the year, and would require a simple heating system in the cold winter for WWR $20 \%, 40 \%$ and $60 \%$. Whereas the rock mass of the mountain acts as a thermal storage unit and works like an earth shelter on the building envelop and by showing the results, the effect of the high thermal mass of rocks are dissolved by increasing the exposed part of the building. Hence, the air temperature is higher in the exposed building than in the Semi excavated building. As the thermal mass decreases the air temperature inside spaces, it reduces the fluctuation in air temperature all over the year, which improves the space environment and avoids the extreme changes inside the spaces within the year seasons, especially in cold winter and hot summer. The orientation has a major effect on the totally excavated building than other types, as the rock acts as a thermal storage.

By comparing the orientations of the totally excavated building, the west direction has the most significant effect on the fluctuation between minimum and maximum temperature all over the year. The gap between minimum and maximum temperature increases by increasing the window to wall ratio, as that gap is highly significant for West direction and decrease by oriented anti clockwise, as shown in Fig. 12. 

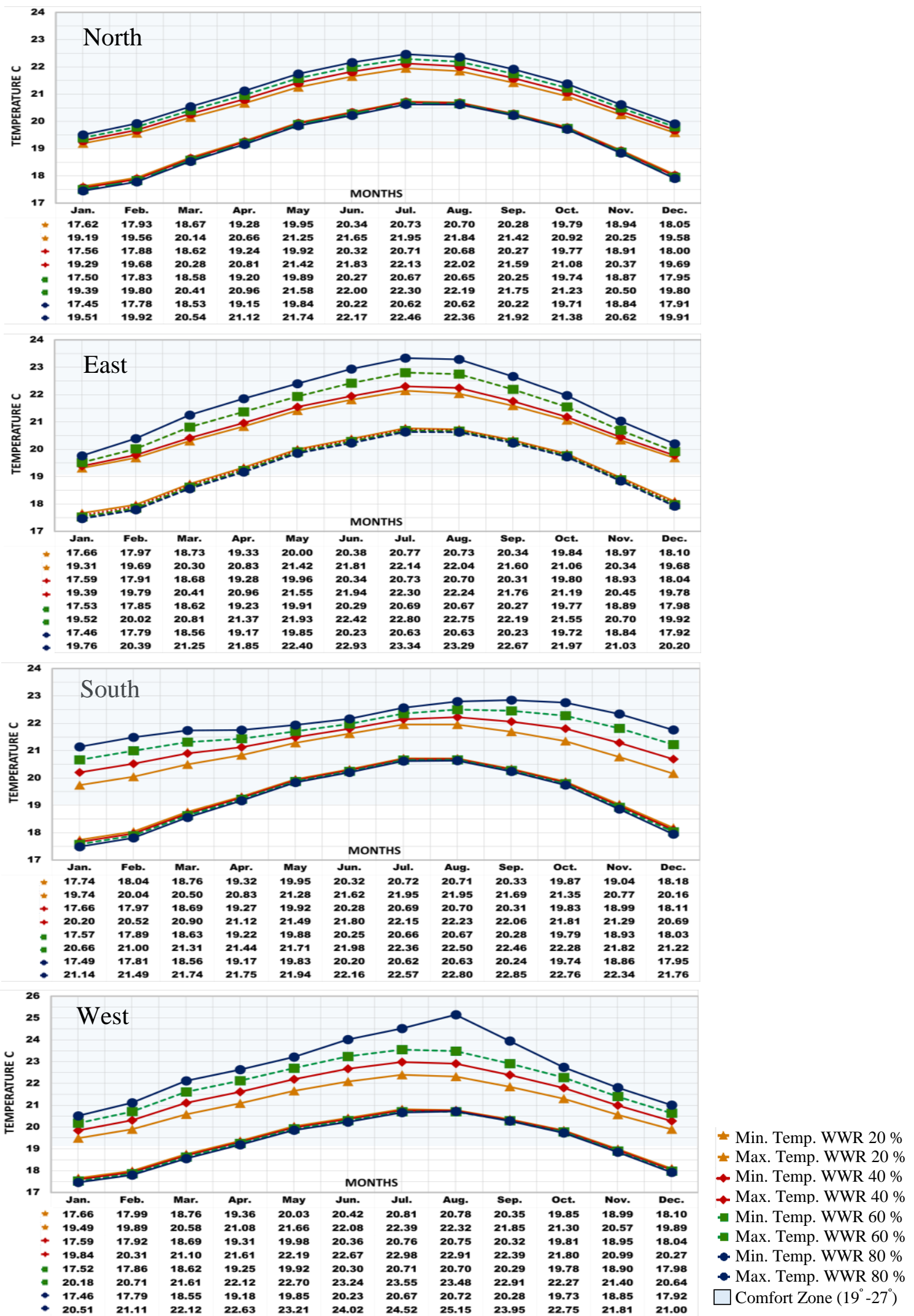

Fig. 12. The totally excavated building orientation effects on temperature by referring to WWR\% 
By comparing the different alternatives of the window to wall ratio for the totally excavated building, it also had a significant impact on the inner spaces temperature, as it effection on the efficiency of the thermal mass storage. That effect increases by increasing the window size. The west oriented building with $80 \%$ WWR has the most significant effect on the fluctuation between minimum and miximum temperature, as shown in Fig. 13 and Fig. 14.
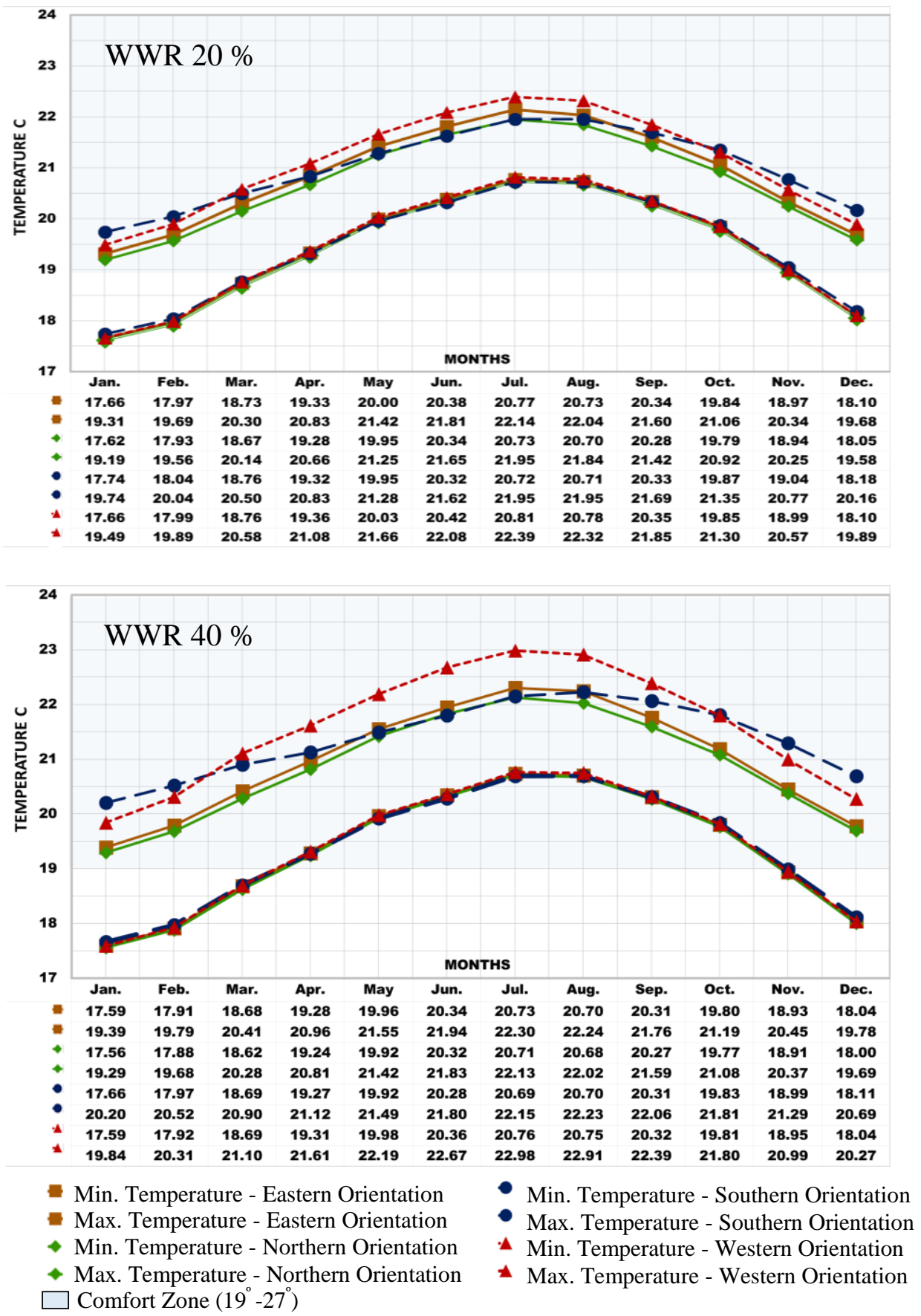

Fig. 13. The effect of the window to wall ratio on space temperature - WWR $20 \%$ and WWR $40 \%$ 

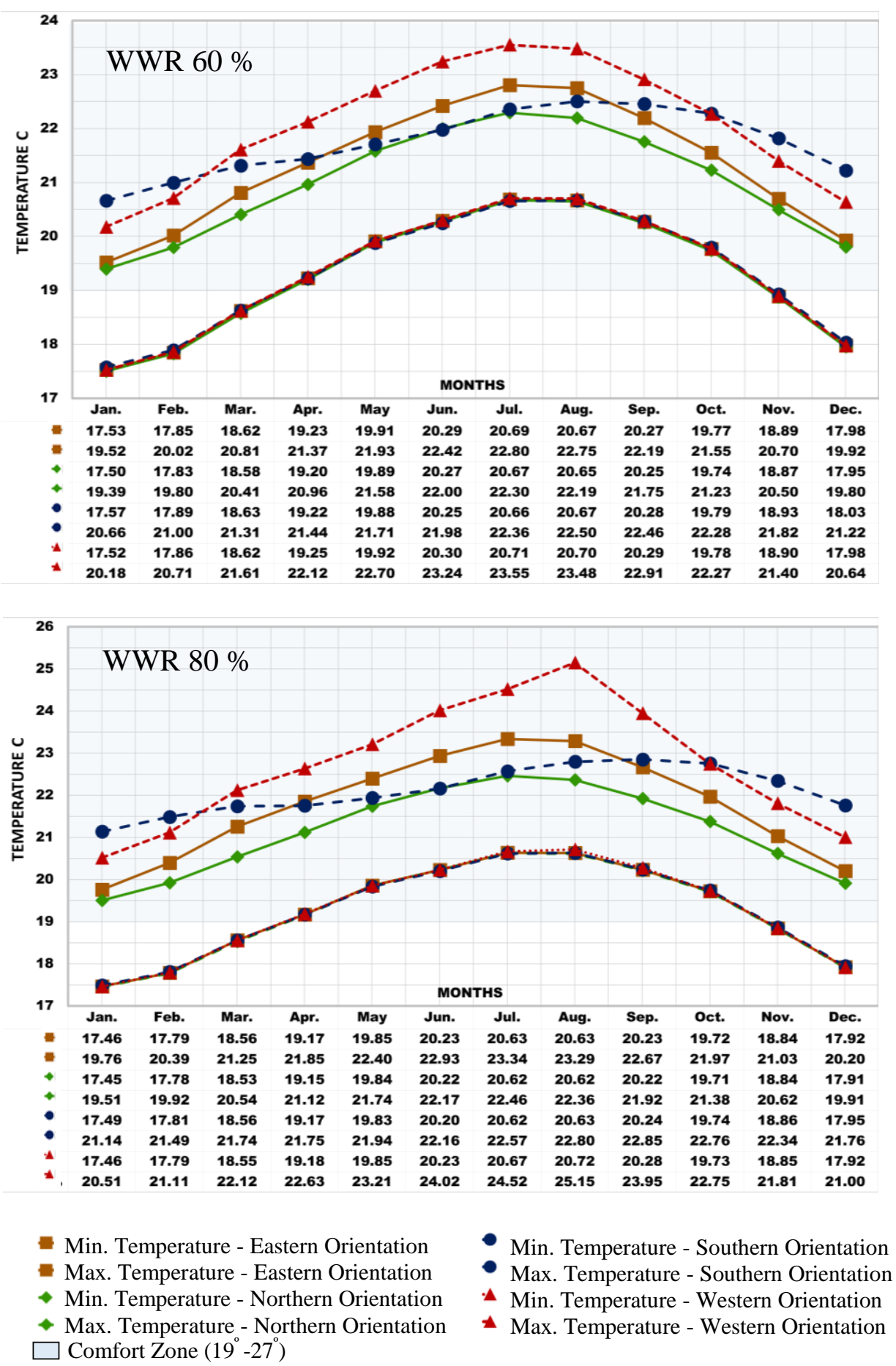

Fig. 14. The effect of the window to wall ratio on space temperature - WWR $60 \%$ and WWR $80 \%$

By simulating the totally excavated building with window to wall ratio $80 \%$, oriented to the Western orientation, the annual results for the minimum and maximum air temperature are within comfort zone in both summer and winter seasons. In addition to that, a constant fluctuation through the year, where the 
maximum temperatures swing between 20.51 and 25.15 degree, while the minimum temperatures swing between 17.46 and 20.72 degree.

The same simulation is applied for an underground building at depth $-2.00 \mathrm{~m}$, and the annual results were found to be within the comfort zone. The underground achieves more stability in the air temperature throughout the year, where the maximum temperatures swing between 19.18 and 21.18 degree, while the minimum temperatures swing between 17.75 and 20.16 degree. Thus, the comparison between an underground building and the totally excavated building shows equivalent results by keeping the building through comfort zone all over the year, as shown in Fig. 15. Nevertheless, the totally excavated building has an additional advantage that the almost full glazed façade which gives adorable view to the outside with the ability to penetrate daylight. While the underground is more effective than totally excavated building with minimal fluctuation in the temperature, but the underground buildings are suffering from darkness, high humidity, and poor ventilation causing bad effects on human beings.

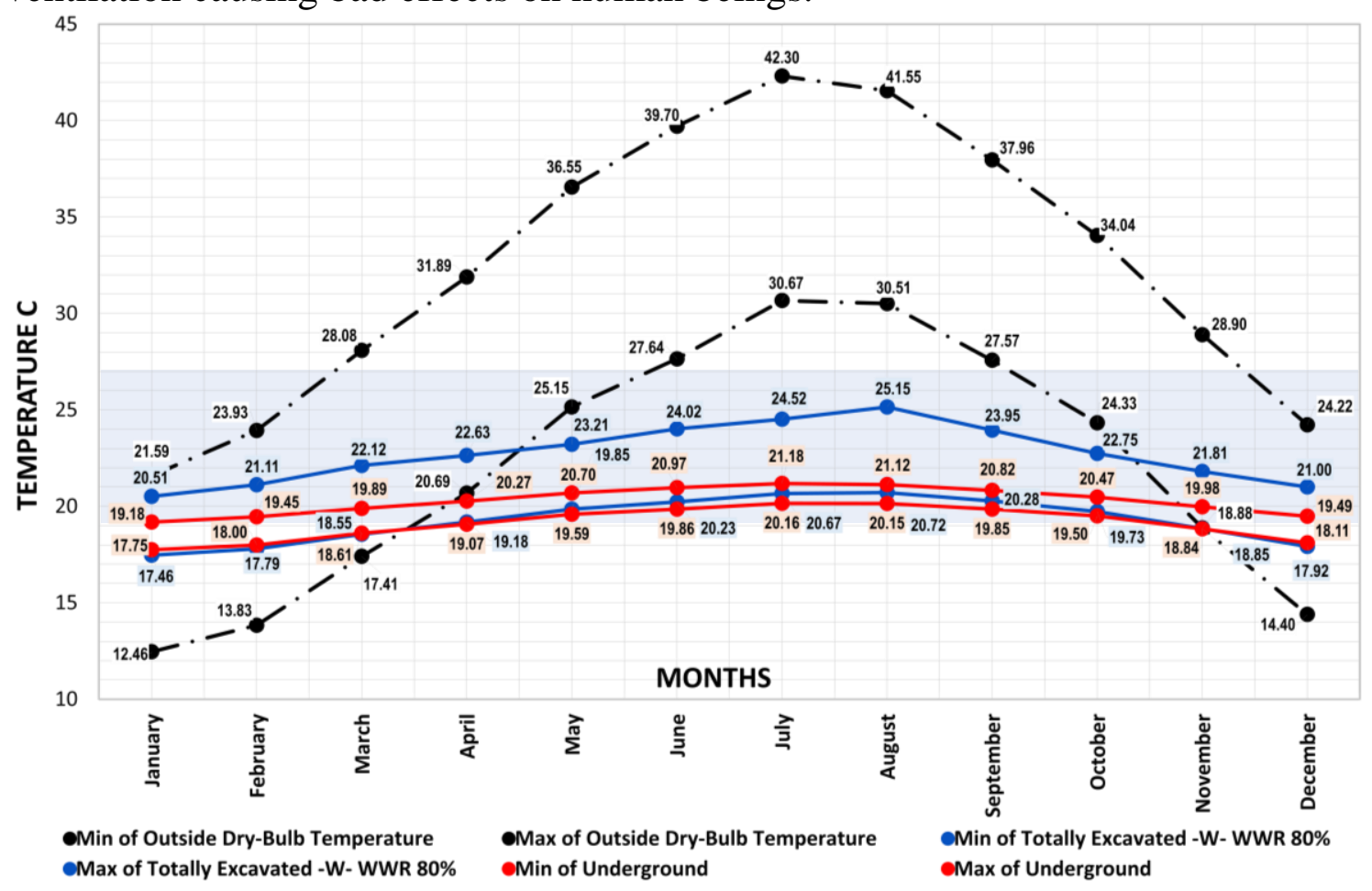

Fig. 15. The average of the Minimum and Maximum temperature annually for an underground building and totally excavated building with WWR $80 \%$ oriented to the Western orientation.

\section{Conclusion}

It is clear that the excavation inside mountain rocks helps in improving building performance, enhancing indoor air temperature and energy saving compared to traditional buildings. Thus, the totally excavated Building is featured by the constant temperature through night and morning and constant temperature through all over the year, where the high thermal mass acts as an earth shelter and thermal 
storage with stability in temperature fluctuation all over the year. As shown in the results, the totally excavated building internal air temperature decreased below the maximum outside air temperature annually by fluctuation from -18 degrees in hot periods and +3 degrees in cold periods. While in the minimum outside air temperature, the fluctuation is by -10 degree in hot periods and +4 degrees in cold periods.

As the totally excavated building is characterized by an exposed façade with wide glazed window, which revokes the underground building disadvantages. Whereas, the exposed façade allows the visual contact with the surrounding environment and improves daylight penetration. It is clearly that the totally excavated building combines between the idea of earth shelter which affords the thermal comfort inside spaces and the idea of being connected with the outside environment.

It is obviously, that the excavated building orientation and exposed façade direction have minor effect on the building performance all over the year, but it has a direct effect on the fluctuation between the maximum and minimum air temperature inside spaces within comfort zone area. Thus, the idea of Visual communication with the environment is strongly achieved whatever the building orientation, which gives a flexibility in the building design.

The excavated cliff buildings are the most suitable alternative for the touristic sector in mountainous lands of Egypt, whereas it is compatible with environment and Necessities of touristic life as the convenient design of the mass and the exposed façade with wide glazing façade overlooking the Red Sea.

\section{References}

[1] Fletcher B. A History of Architecture. Twentieth. Daryaganj, New Delhi: CBS Publishers \& Distributors Pvt. Ltd; 1996.

[2] Overseas Development Institute. Disaster Risk Reduction. vol. July. Springer; 2015. doi:10.1007/978-4-431-55242-0.

[3] FAO. Why invest in sustainable mountain development? Food and Agriculture Organization of the United Nations (FAO); 2011.

[4] Cavcar M. The International Standard Atmosphere (ISA). Anadolu Univ Turkey 2000:1-7.

[5] The free dictionary. Excavate n.d. https://www.thefreedictionary.com/excavated (accessed October 24, 2017).

[6] Crescenzi C, Caprara R, editors. Common Identity - New Perspective The Rupestrian Ssttlements in the Circum-Mediterranean area. Firenze: Università degli studi di Firenze; 2012.

[7] Correia, M., Dipasquale, L., \& Mecca S. Heritage for tomorrow - Vernacular Knowledge for Sustainable Architecture. Italy: FIRENZE UNIVERSITY PRESS; 2010.

[8] Noble AG. Traditional Buildings: A Global Survey of Structural Forms and Cultural Functions. London: I.B. Tauris; 2007.

[9] Klodt G. Earth sheltered housing. Reston,Virginia: Reston publishing company,A Prentice-Hall company; 1985. 
[10] Palmer AL. Historical Dictionary of Architecture. United States of America: The Scarecrow Press,Inc.; 2008.

[11] Sassa K, Fukuoka H, Wang F, Wang G. Landslides Risk Analysis and Sustainable Disaster Management. 2005.

[12] great buildings. Hatshepsut's Temple n.d. http://www.greatbuildings.com/cgibin/gbc-drawing.cgi/Hatshepsuts_Temple.html/Hatshepsut_Temple_Sec.jpg (accessed February 25, 2018).

[13] FloridaCenter. Cross Section of the Great Temple at Abu Simbe n.d. http://etc.usf.edu/clipart/59100/59162/59162_abu_simbelcs.htm\%0A\%0A (accessed February 25, 2018).

[14] Meteonorm. Irradiation data for every place on Earth 2010. http://www.meteonorm.com/en/.

[15] ANSI/ASHRAE/IESNA Standard 90.1-2007. ASHRAE STANDARD Energy Standard for Buildings Except Low-Rise Residential Buildings. vol. 8400. 2007. doi:http://dx.doi.org/10.1108/17506200710779521. 


\title{
الراحة الحرارية لمباني المنحدرات المحفورة بمنطقة طابا بجنوب سيناء
}

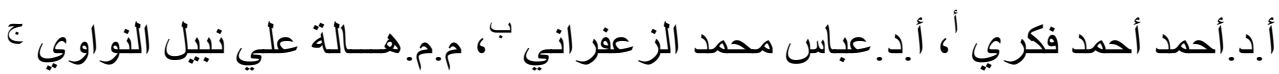

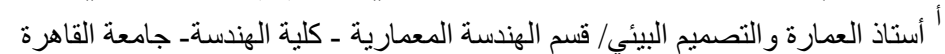

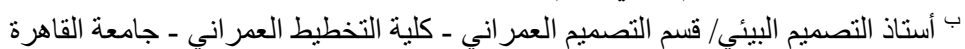 \\ ج طالبة دكتور اه/ تخصص تصميم بيئي ـ قسم الهندسة المعمارية ــ كلية الهندسة- جامعة القاهرة
}

الملخص

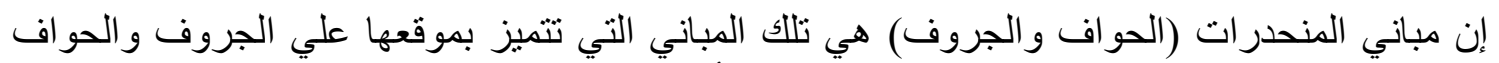

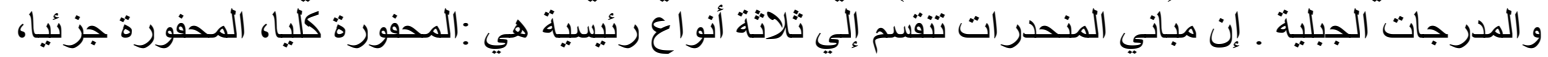
الغير محفورة كليا. إن مباني الجروف تتميز بإرتفاعها عن منسوب سطح البحر مما يمنحها موقع فريد

وخصوصية.

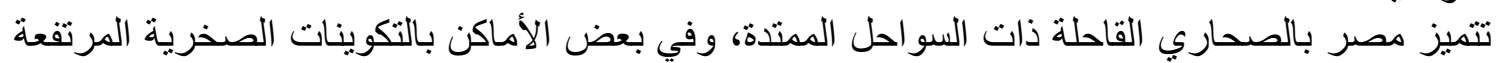

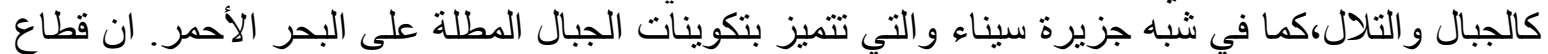

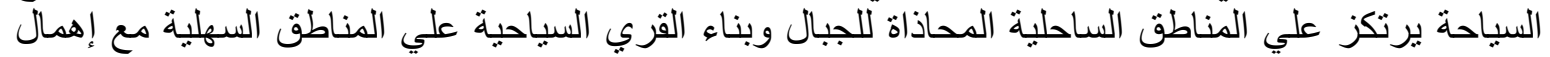

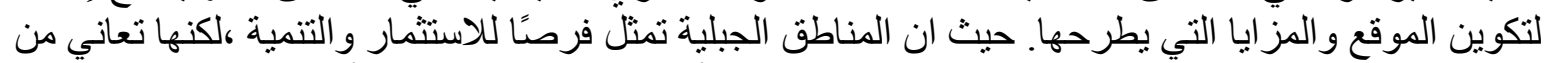

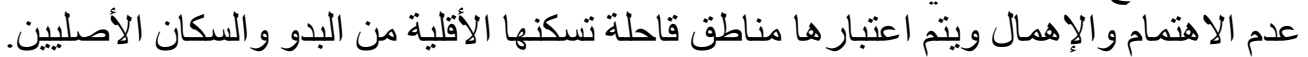

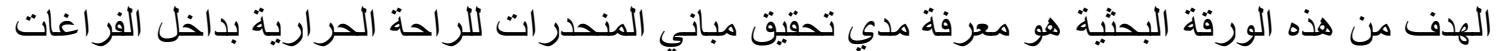

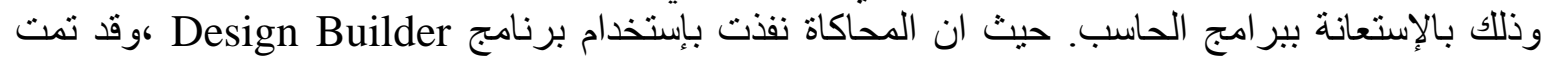

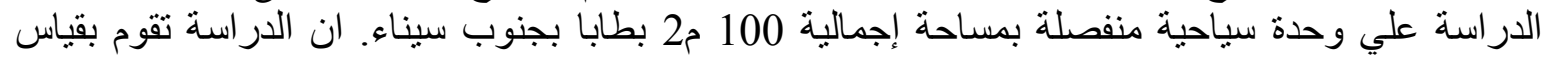

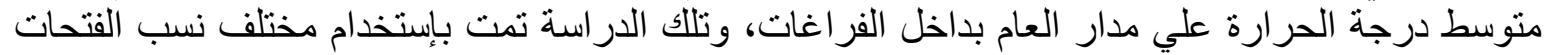
للحائط وكذللك تطبيقها علي الإتجاهات الرئيسية الأربعة. حيث توضيح مدي ألئي أهمية الإستفادة من البناء

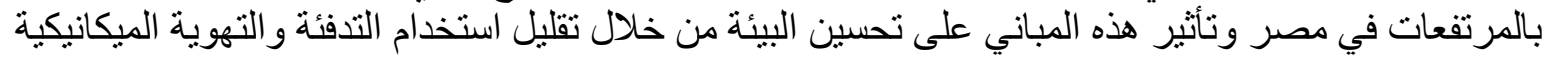

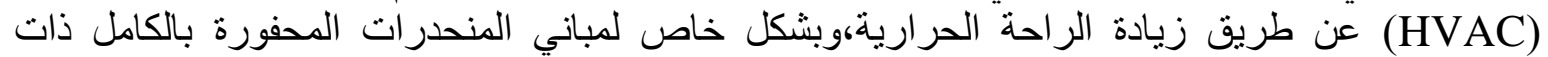
الو اجهة المكثوفة حيث تقع ضمن منطقة الر احة الحر ارية علي الرة مدار العام.

الكلمات المفتاحية

مباني الحواف، المباني المحفورة، المباني المحفورة جزئيا، طابا ـ مصر، الراحة الحرارية. 